Case Report

\title{
Historic Building Energy Audit and Retrofit Simulation with Hemp-Lime Plaster-A Case Study
}

\author{
Rosa Agliata $®$, Alfonso Marino, Luigi Mollo and Paolo Pariso *(i) \\ Department of Engineering, University of Campania “L. Vanvitelli”, 81031 Aversa (CE), Italy; \\ rosa.agliata@unicampania.it (R.A.); alfonso.marino@unicampania.it (A.M.); luigi.mollo@unicampania.it (L.M.) \\ * Correspondence: paolo.pariso@unicampania.it; Tel.: +39-0815010332
}

Received: 15 April 2020; Accepted: 3 June 2020; Published: 5 June 2020

check for updates

\begin{abstract}
Hemp-lime composite is a natural material, which is being increasingly used and studied in the construction sector, thanks to its recyclability, hygrothermal comfort and healthiness features. The aim of this paper is to test the benefits in terms of energy efficiency achieved through the use of hemp-lime composite as insulation in a possible refurbishment intervention. With the aim of extending the knowledge about the benefits achieved through from the integration of this natural material into construction production process, a real building in south of Italy was selected and a substitution of the standard gypsum-lime plaster with a hemp-lime one was simulated by means of a specific software (Termus ${ }^{\circledR}$ by Acca Sotware, Bagnoli Irpino, Italy), serving for the assessment of the energy performance. Case study analysis highlighted the good thermal insulation properties of hemp-based plaster, allowing thermal dispersion to decrease in the winter season and improve the summer performance of the walls by approximately $20 \%$ compared to traditional plaster. This results in a one-level improvement of the building in energy classification according to Italian regulation.
\end{abstract}

Keywords: sustainability; sustainable materials; energy audit; energy simulation; energy retrofit; built heritage; hemp-lime

\section{Introduction}

The transition from the linear economy towards the circular economy implies a deep transformation of the productive systems and has significant implications for the economy, society and the environment. [1]. In particular, environmental impact is a pivotal theme that is being increasingly implemented in the economic development of all sectors [2], particularly those with high pollution rates, such as the AEC (architecture, engineering and construction) industry [3]. Buildings and other structures entail many environmental issues during construction, operation, maintenance and destruction phases, such as large waste production, huge energy demand and high consumption of raw materials and natural resources [4]. As the use of non-renewable resources is universally considered unsustainable and likely to damage the environment [5], it is necessary to develop alternative strategies to meet human needs from a long-term perspective while safeguarding both people and the planet, considering the life cycle assessment (LCA) of buildings in both new edifications and refurbishment interventions [6]. Over the past years, building sustainability and LCA have become crucial topics [7], increasing interest in low- and zero-emission buildings and construction methods that can facilitate the reduction of $\mathrm{CO}_{2}$ emissions [8], fossil fuel consumption and energy intake [9], according to the latest European regulations [10,11]. However, up until recently, eco-building has mainly focused on energy efficiency during service life, making use of high-performance insulation [12], renewable energy and rainwater collection, yet continuing to build structures from petrochemical-based synthetic materials. Concrete, steel and plastic are among the most used materials in the AEC industry; they have high energy demand, toxic production processes, do not biodegrade easily and are not suitable to 
be disposed of in a landfill [13]. Also, many building components and insulation products make use of noxious additives like glues, binders and flame-retardants (e.g., brominated artefacts).

Only lately have the nature of the materials and methods started to be considered as equally important [14], making eco-friendly materials assume a fundamental role in the concept of sustainable development in the AEC sector. Thus, society has begun to look for sustainable materials that are renewable (i.e., materials that can be replaced, regenerated and reused without damaging the environment), less pollutant, consume minimal fossil fuel energy and have low level of greenhouse gas emission and health risk [15]. In Europe, in the last few years, a lot of effort has been allocated in this direction, taking and implementing many operative actions. For example, a number of EU research project on these topics have been funded, such as the "Energy Efficiency for EU Historic Districts Sustainability" (EFFESUS) [16] and the "Robust Internal Thermal Insulation of Historic Buildings" (RiBuild) [17]. In these projects, themes linked to energy efficiency are widely developed and experimental, operative and methodological outcomes are shared, especially regarding the thermal retrofit of historic built heritage by means of innovative insulation materials (e.g., aerogel) $[18,19]$, relating energy benefits to economic ones by using the "Cost Optimality" methodology [20] and evaluating the proposed thermal insulations in a life cycle perspective [21]. Results of these studies are interesting and promising, but the tested products, tools and experimental procedures are not based on the use of "natural based solutions". The demand for natural and non-toxic construction materials as an alternative to synthetic products, ensuring at the same time a high level of performance, is growing rapidly as public awareness of green issues has grown [22]. Moreover, the use of natural based materials in the AEC sector and in particular for historical building is considered as optimal by many recent studies [23-28] Despite this ever more growing interest and the fact that a large part of eco-friendly building materials is already natural based, only a few operational and experimental data are available on their application to historical built heritage. This work tries to create an accumulation of knowledge on this issue, providing information to researchers and designers on the use of a natural-based material as insulations in a historical building. The chosen material is hemp-lime, a composite construction material that can be used in many forms (bricks, panels, paste, etc.) and for many scopes (e.g., insulation for walls, roofs and floors or as a part of timber-framed construction). Thanks to their insulation, health and recyclability features, hemp-based materials for building applications are increasingly catching researchers' attention [29]. The aim of this paper is to test the benefits in terms of energy efficiency by means of energy performance indexes (i.e., thermal dispersions, hygrometric behaviour, energy consumption, $\mathrm{CO}_{2}$ emissions and $\mathrm{EU}$ energy efficiency rating) deriving from the use of hemp-lime composite as insulation.

This paper, after an evaluation of critical and beneficial points of hemp products, presents the analysis of a case study. The hemp was also chosen because it is produced and processed in the area where the historic building is located, therefore hemp can be supplied at zero kilometre. For this aim, a real building in chosen and its thermal behaviour is calculated, by means of a specific software (Termus ${ }^{\circledR}$ by Acca Software), in both present condition and simulating a building refurbishment operation in which hemp-lime plaster is used to replace the standard one.

\section{Challenges and Benefits of Hemp Use in AEC Sector}

Challenges that AEC is nowadays facing to reduce its environmental impact are summarized in Table 1. In the left-hand column, the primary role of the AEC sector is displayed, highlighting its global importance that transversally produces significant effects in different contexts; the right-hand column displays the objectives that the sector should reach in terms of sustainability are shown. As an example, one of the primary issues in the AEC industry is the fact that it entails a large consumption of raw materials generating both high energy consumption (see Table 1, Challenge 1) and high level of wastes (see Table 1, Challenge 3). Thus, considering the life cycle assessment of the buildings and their network infrastructures (i.e., water and waste water systems), choosing sustainable construction materials, to be regenerated and reused, with low level of greenhouse gas emission and ensuring high level of 
performance, can increase the sustainability of the sector [30] (see Table 1, Challenge 2). As society has begun looking for natural materials that are renewable (i.e., materials that can be replaced without damaging the environment), consume minimal fossil fuel energy, and have minimal pollution and health risk (see Table 1, Challenge 4), a large part of building eco-friendly materials have started being natural fibre based [31].

Moreover, the concept of sustainability should also be seen as a financial resource. In particular, considering the economic primary role of the AEC sector, activities such as the assessment of end of life and maintenance costs (see Table 1, Challenge 5) could be strategic to improve the use of financial resources. Economic sustainability should focus on keeping the economic gains of industry within the local community. Promoting locally run businesses and employing locals can help local communities in profiting within AEC sector $[32,33]$ and in creating a sustainable design focused on reducing at minimum the distances between producers and consumers.

In order to pick up the five challenges shown in Table 1, it is necessary to address all the barriers hampering the establishment of the use of hemp, creating enough balance between efficiency and resilience. A summary of initial barriers for Italian hemp building industry is reported in Table 2 . The six pillars (technical, commercial, knowledge, regulatory, psychological and invisible), designed as complex chains involving a great number of actors and consumers, are not always able to identify the producers of raw materials $[34,35]$. For example, it would also be strategic to consider the hemp certification process as an important aspect for the creation of a sustainable pattern, able to guarantee credibility of the products related to the hemp sector [36].

Table 1. Sustainability challenges in architecture, engineering and construction (AEC) sector. Source: our elaboration from [37-41].

\begin{tabular}{|c|c|c|}
\hline Challenges & Primary Role of the AEC Sector & Sustainable AEC Sector Objectives \\
\hline $\begin{array}{l}\text { 1. Savings in } \\
\text { the supply of } \\
\text { power }\end{array}$ & $\begin{array}{l}\text { - } 40 \% \text { of the total energy consumption comes } \\
\text { from } 160 \text { million buildings. } \\
\text { 2/3 of energy consumption in buildings are used } \\
\text { for heating and air conditioning. } \\
\text { - } 3.3 \text { million barrels of oil could be saved every } \\
\text { year in Europe if the buildings were made more } \\
\text { efficiently from the energy viewpoint. }\end{array}$ & 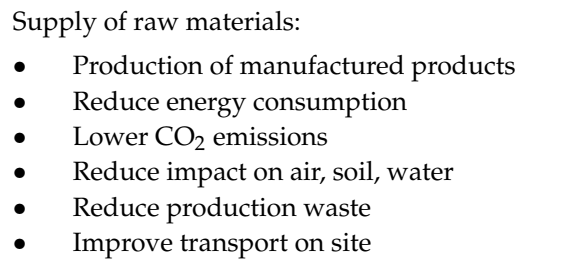 \\
\hline $\begin{array}{l}\text { 2. Mitigation of } \\
\text { climatic change }\end{array}$ & $\begin{array}{l}\text { - } 460 \text { million tons of } \mathrm{CO}_{2} \text { could be saved every } \\
\text { year in Europe by energy-efficient measures } \\
\text { from an energy point of view in buildings. } \\
\text { Buildings are primarily responsible for } \\
\text { greenhouse gas emissions and represent } 36 \% \text { of } \\
\text { the } \mathrm{CO}_{2} \text { emissions in Europe }\end{array}$ & $\begin{array}{l}\text { Use of resources: } \\
\text { - } \quad \text { Improve quality of the building (estate air) } \\
\text { - } \quad \text { Reduce waste production } \\
\text { - } \quad \text { Make more efficient the use of water } \\
\text { - } \quad \text { Reduce } \mathrm{CO}_{2} \text { emissions } \\
\text { - } \quad \text { Make more effective maintenance } \\
\text { - } \quad \text { and replacement }\end{array}$ \\
\hline $\begin{array}{l}\text { 3. Waste } \\
\text { management } \\
\text { and protection } \\
\text { of resources }\end{array}$ & $\begin{array}{l}\text { Construction in the Organisation for Economic } \\
\text { Co-operation and Development (OECD) } \\
\text { countries is responsible from } 30 \text { to } 40 \% \text { of solid } \\
\text { waste creation, } 30 \% \text { of use of raw materials and } \\
10 \% \text { of land cultivated. }\end{array}$ & $\begin{array}{l}\text { Dismantling, demolition in situ, recovery, } \\
\text { disposal and transport: } \\
\text { - } \quad \text { Reduce impact of waste from demolition } \\
\text { - } \quad \text { Improve the sustainability in construction } \\
\text { and assessment skills in time }\end{array}$ \\
\hline $\begin{array}{l}\text { 4. Health and } \\
\text { wellness } \\
\text { economic } \\
\text { growth }\end{array}$ & $\begin{array}{l}\text { In Europe alone, } 8 \text { billion euros could be saved } \\
\text { every year in health and economic costs related } \\
\text { to air pollution, simply by improving insulation. }\end{array}$ & $\begin{array}{l}\text { Improve workers' health and safety on } \\
\text { construction sites: } \\
\text { - } \quad \text { Reduce disorders of the neighbourhood } \\
\text { (noise, dust, congested traffic) } \\
\text { - } \quad \text { Improve performance in place compared to } \\
\text { project performance Solutions for thermal } \\
\text { and acoustic comfort: } \\
\text { - } \quad \text { Improve safety (fire protection) } \\
\text { - Preserve health (indoor air quality) }\end{array}$ \\
\hline
\end{tabular}


Table 1. Cont.

\begin{tabular}{clll}
\hline Challenges & \multicolumn{1}{c}{ Primary Role of the AEC Sector } & \multicolumn{1}{c}{ Sustainable AEC Sector Objectives } \\
\hline & - & $\begin{array}{l}\text { Between } 10 \text { and } 28 \% \text { of European family income } \\
\text { is for home maintenance and repair, water } \\
\text { supply, electricity, gas and other fuels for } \\
\text { domestic use. }\end{array}$ & $\begin{array}{l}\text { End-of-life costs: } \\
\text { Improve processes of dismantling, } \\
\text { demolition and recovery/ disposal }\end{array}$ \\
$\begin{array}{c}\text { 5. Financial } \\
\text { resources } \\
\text { availability }\end{array}$ & - $\begin{array}{l}\text { Up to 530,000 jobs could be created in Europe } \\
\text { through a strategy ambitious aimed at } \\
\text { improving efficiency energy in buildings [35] } \\
\text { A strong increase in regulations energy in } \\
\text { construction in Europe could lead to an increase } \\
\text { of 700,000 additional jobs in AEC sector }\end{array}$ & - $\begin{array}{l}\text { Maintenance costs } \\
\text { Reduce external costs: heating, air } \\
\text { conditioning, water, electricity } \\
\text { Reduce purchase and construction costs }\end{array}$ \\
\hline
\end{tabular}

Table 2. Initials barriers for hemp building industry mainstreaming.

\begin{tabular}{|c|c|c|c|c|c|}
\hline Technical & Commercial & Knowledge & Regulatory & Psychological & Invisible \\
\hline
\end{tabular}

\subsection{Technical Standpoint}

In the last decade, following the growing interest generated by hemp, a number of hemp-based materials have been developed in the AEC industry [42,43], such as hemp-concrete [44-46] and various types of insulations for use both internally and externally [47]. Among these natural based composites, some result from the combination of a mineral binder matrix with shives aggregate [48] and can be used for envelopes as well as internal partitions. Among the hemp-based composites, hemp-lime plays a main role, since it can be used as premixed mortar (e.g., simply sprinkled) plus it is the main component to produce all hemp-based composites in different forms, like bricks and panels [49].

Several studies focused on the hemp-lime properties, among which one of the most interesting is the ability to sequestrate $\mathrm{CO}_{2}$ during manufacturing, both in the hemp plant growing phase and in the lime production process, so that this composite can be considered as a carbon negative material [50]. Moreover, the composite is breathable and healthy [51] and a bad thermal conductor, thus ensuring good insulation [52-54], good soundproofing [55] and fire resistance properties [56]. Its load bearing capacity is quite poor, so it is not made for structural purposes, however it can be used as infill wall for wooden frames $[57,58]$. Lastly, hemp-lime also ensures protection against infestations with very little toxicity [59]. Thanks to the described features, hemp-lime is being increasingly studied and used as thermal insulation for buildings energetic retrofit operations as well as new constructions [44]. It is interesting to note, despite these potentialities, that technical barriers are linked to the lack of expertise in both production, with few businesses having yet achieved significant industrial dimensions, and use, with the presence of $94 \%$ of micro enterprises (1 to 9 employees) in the Italian AEC sector (ISTAT, 2018).

\subsection{Commercial Standpoint}

Despite the production of industrial hemp being developed in more than 35 countries in the world, only in the last 15 years has there has been an increase of such cultivation. In fact, in 2004 the hemp cultivation area expressed in ha within European countries was 14,932 [60], and in 2016 was 33,300 [61]. This trend, 2004-2016, is the result of several factors; on one hand, the increase of the demand for natural products, the growth of awareness about environment sustainability and the rise of raw material and petrol costs; on the other hand, the improving of techniques, cultivation practices and industrial equipment. In line with this assumption, industrial hemp production should be profitable from an economic standpoint, since it should be competitive not only with other fibres, but with other 
production alternatives as well. Some of the barriers limiting hemp commercial development and causing potential profitability issues for the farmers is the lengthy storage period required during the winter season before being further processed and the transportation costs, which could have a negative implication on hemp economic and environmental feasibility. In fact, this material has a low bulk density [62], and in turn, its value per ton is fairly low for transportation while high for storage [63].

\subsection{Knowledge Standpoint}

Among the stakeholders, a general lack of knowledge on lime-hemp exists [64] Usually, they ignore the potential advantages of its application and the overcoming of this barrier starts first of all by the stakeholders of the AEC sector that could realize it thanks to the increase in its use, creating a higher visibility and consequently more consciousness in the general context.

\subsection{Regulatory Standpoint}

Orienting adequate government actions to a favourable legislation means recognizing a positive identity to hemp linked both to the crop, with quality certification ensuring national quality standards, and to hemp-lime as a construction material, in that way affecting the AEC sector. In line with this, thanks to its features of being easily cultivable, hemp cultivation could be a profitable alternative.

\subsection{Psychological Standpoint}

Despite there being a great difference between hemp and marijuana, public opinion seems to be confused associating hemp to recreational drug uses [65]. Naturally, it could be beneficial to counteract the lack of knowledge with an increase of awareness about this product. In addition, environmentally friendly solutions are generally associated only with reduced heating costs in AEC sector, belittling materials such as hemp-lime that also offers other well-established benefits.

\subsection{Invisible Standpoint}

The growing of hemp-lime industry inevitably creates, in the AEC sector, a competitive market that could harm the niche market of materials that do not have a consolidated and strong market position. This initial invisible barrier is linked to the competitiveness of other similar products that are used in the AEC sector such as synthetic fibres.

\section{Materials and Methods}

For its characteristics, hemp-lime is considered as a suitable material for energy retrofit of historic buildings [66]. Many historic buildings have been studied at full-scale, to evaluate the effects of hemp-lime use on their energetic performance [67]. In this work, the effective increase in the energy performance of a historic-monumental building generated by use of lime -hemp at full scale was evaluated. The chosen case study was "Palazzo Jadicicco", a historical courtyard building built in the second half of 17th century in Frattamaggiore, a town located in the suburban belt of Naples that was an important site for hemp production until the Second World War [68]. In 1780 Michele Niglio Jadicicco, poet and officer of king's personal guard, decided to restore the palace following the late Baroque style, an expression of the refined and aristocratic spirit of the Kingdom of Naples. The palace has a smooth ashlar ground floor façade, separated by a fluted band from the upper part, where windows alternate with balconies. The main entrance is a large arch in Vesuvian stone leading to a wide courtyard where in past times garages for carriages, stables and cellars faced. Rooms on the ground floor facing the street have a total area of $255 \mathrm{~m}^{2}$ with a height of $5 \mathrm{~m}$ and are used for commercial purposes; upper rooms are all intended for homes and most of them still preserve the original 18th century style, with frescoes, stuccoes and floorings. Figures 1 and 2 show plans, elevation and an axonometric of the case study. 


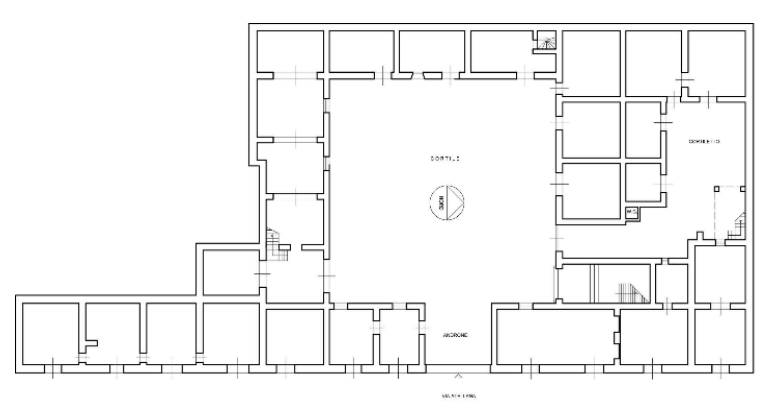

a)

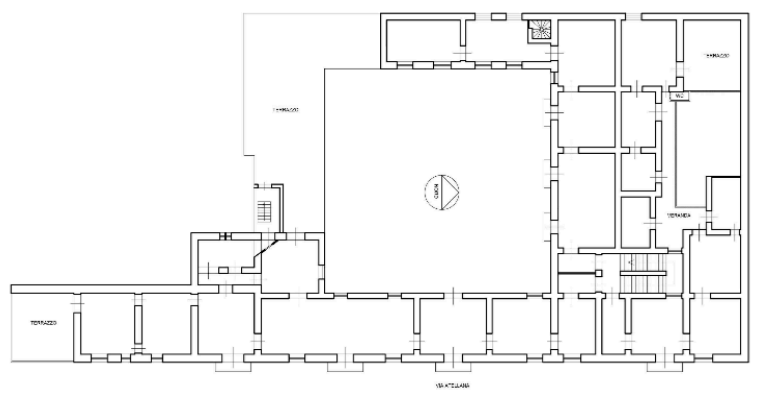

b)

Figure 1. Floorplans of the case study: (a) ground floor; (b) first floor.

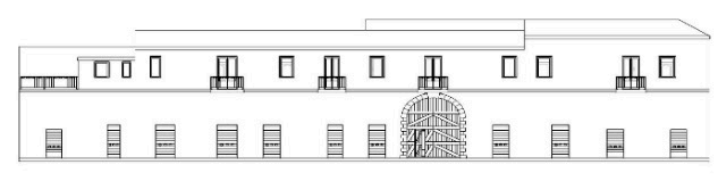

a)

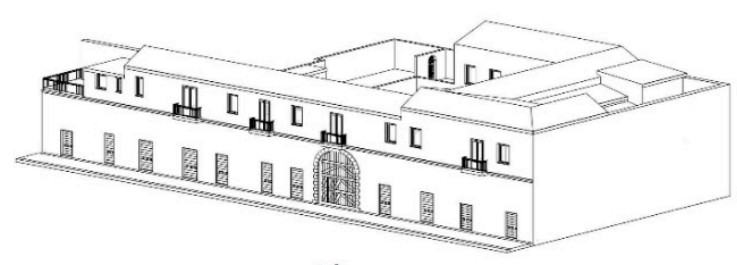

b)

Figure 2. Case study: (a) street façade elevation; (b) axonometric projection.

The building has a load-bearing masonry structure made with Yellow Neapolitan Tuff (YNT), a volcanic material very widespread in South Italy, used for centuries to build vertical barriers of any kind of construction in Campania Region. The external walls facing the street have a granite coating on the external façade and gypsum lime plaster (GL-P) on the internal one, while the other walls are coated on both sides with plaster. Some other partitions are made with hollow bricks (HB), also coated with plaster on both sides. The characteristics of all existing materials, alongside hemp-lime plaster (HL-P) are reported in Table 3. The software calculated thermal resistance and thermal admittance.

Table 3. Characteristics of all materials.

\begin{tabular}{ccccc}
\hline Material & $\begin{array}{c}\text { Thermal } \\
\text { Conductivity } \\
\boldsymbol{\lambda}[\mathbf{W} / \mathbf{m K}]\end{array}$ & $\begin{array}{c}\text { Surface Mass } \\
\text { Density } \\
\text { s.m.d. }\left[\mathbf{k g} / \mathbf{m}^{2}\right]\end{array}$ & $\begin{array}{c}\text { Steam Permeab. } \\
\mathbf{( R H} \leq \mathbf{5 0} \mathbf{)}) \\
\mathbf{P}[\mathbf{k g} / \mathbf{m s P a}]\end{array}$ & $\begin{array}{c}\text { Specific Heat Cap. } \\
\mathbf{c}[\mathbf{J} / \mathbf{k g K}]\end{array}$ \\
\hline Yellow Neapolitan Tuff & 1.70 & 23 & 0.02 & 1380 \\
\hline Hollow bricks & 0.25 & 6 & 36.00 & 840 \\
\hline Gypsum lime plaster & 0.70 & 14 & 18.00 & 1000 \\
\hline Hemp-lime plaster & 0.12 & 5 & 43.00 & 1200 \\
\hline \multicolumn{5}{r}{ Characteristics marked with * refer to a $10 \mathrm{~mm}$ thickness layer. }
\end{tabular}

Different wall layouts are distinguished, depending on the wall position (layouts with one side facing the outside and the other the inside are called "envelope", while layouts with both sides facing indoor areas are called "partition"), materials and thickness, nine in total, whose features are reported in Table 4. 
Table 4. Wall layouts.

\begin{tabular}{|c|c|c|c|c|c|c|c|c|}
\hline \multicolumn{3}{|c|}{ LAyout A1 } & \multicolumn{3}{|c|}{ Layout A2 } & \multicolumn{3}{|c|}{ Layout A3 } \\
\hline Layer $n^{o}$ & Material & $\begin{array}{c}\text { Thickness } \\
\text { [mm] }\end{array}$ & Layer $\mathbf{n}^{\mathbf{o}}$ & Material & $\begin{array}{c}\text { Thickness } \\
\text { [mm] }\end{array}$ & Layer $\mathbf{n}^{\mathbf{o}}$ & Material & $\begin{array}{c}\text { Thickness } \\
\text { [mm] }\end{array}$ \\
\hline 1 & GL-P & 20 & 1 & GL-P & 20 & 1 & GL-P & 20 \\
\hline 2 & YNT & 660 & 2 & YNT & 660 & 2 & YNT & 560 \\
\hline 3 & GL-P & 20 & 3 & GL-P & 20 & 3 & GL-P & 20 \\
\hline Total & & 700 & Total & & 700 & Total & & 600 \\
\hline \multicolumn{3}{|c|}{ envelope } & \multicolumn{3}{|c|}{ partition } & \multicolumn{3}{|c|}{ envelope } \\
\hline \multicolumn{3}{|c|}{ LAYOUT A4 } & \multicolumn{3}{|c|}{ Layout A5 } & \multicolumn{3}{|c|}{ Layout A6 } \\
\hline 1 & GL-P & 20 & 1 & GL-P & 20 & 1 & GL-P & 20 \\
\hline 2 & YNT & 560 & 2 & YNT & 510 & 2 & YNT & 460 \\
\hline 3 & GL-P & 20 & 3 & GL-P & 20 & 3 & GL-P & 20 \\
\hline Total & & 600 & Total & & 550 & Total & & 500 \\
\hline \multicolumn{3}{|c|}{ partition } & \multicolumn{3}{|c|}{ partition } & \multicolumn{3}{|c|}{ envelope } \\
\hline \multicolumn{3}{|c|}{ Layout A7 } & \multicolumn{3}{|c|}{ Layout A8 } & \multicolumn{3}{|c|}{ Layout A9 } \\
\hline 1 & GL-P & 20 & 1 & GL-P & 20 & 1 & GL-P & 10 \\
\hline 2 & YNT & 460 & 2 & YNT & 360 & 2 & HB & 80 \\
\hline 3 & GL-P & 20 & 3 & GL-P & 20 & 3 & GL-P & 10 \\
\hline Total & & 500 & Total & & 400 & Total & & 100 \\
\hline \multicolumn{3}{|c|}{ partition } & \multicolumn{3}{|c|}{ partition } & \multicolumn{3}{|c|}{ envelope } \\
\hline
\end{tabular}

It is worth noting that the study excludes the external wall facing the street covered with granite stone since no render substitution was possible for those walls. All identified envelopes belong to the external barrier facing the internal court, where there is no granite cover. Details about other elements, such as slabs, windows, MEP (mechanical, electrical and plumbing) systems, etc., are not described here because they are not significant for the purpose of this study, since they are kept constant in the simulation of the refurbishment intervention. In fact, the latter concerns only the substitution of renders and plasters not covered by frescos, in the perspective of protecting the aesthetic characteristics of the building. For the same reason, the substitution of ceiling plasters is not considered either, since most of the ceilings are decorated with frescoes dating back to the construction.

For the evaluation of the building energy performance, two conditions are considered: a) as it is, and $b$ ) replacement of the standard internal plaster and external render with a hemp-lime one, from 4 to $7 \mathrm{~cm}$ thick [69], depending on the wall side (internal or external) and type (tuff or bricks masonry). To achieve such thickness, hemp-lime plaster should be laid in three steps, each corresponding to a layer: the first layer, called "scratch coat", is rich in lime and has to be applied with a trowel, so as to obtain a perfect adhesion to the wall and a rough surface for a better grip of the next layer. The second layer is the crinkle and is applied with a smooth trowel or an American spatula with a thickness between 2 and $5 \mathrm{~cm}$. The finishing layer has to be lime-based, especially on the external walls, to protect the hemp-lime from atmospheric agents; for this layer, a smaller size of the shives can be selected if a finer appearance is desired. All layers can also be applied as a spray.

Comparing the two situations, it is possible to assess the benefits deriving from this type of refurbishment intervention. Table 5 reports the resulting layouts after the simulated installation of the hemp-lime plaster. Layers are listed from inside to outside. 
Table 5. Wall layouts after hemp-lime lying simulation.

\begin{tabular}{|c|c|c|c|c|c|c|c|c|}
\hline \multicolumn{3}{|c|}{ LAYOUT B1 } & \multicolumn{3}{|c|}{ LAYOUT B2 } & \multicolumn{3}{|c|}{ LAYOUT B3 } \\
\hline Layer $\mathrm{n}^{\mathbf{o}}$ & Material & $\begin{array}{l}\text { Thickness } \\
\text { [mm] }\end{array}$ & Layer $\mathrm{n}^{\mathbf{o}}$ & Material & $\begin{array}{c}\text { Thickness } \\
\text { [mm] }\end{array}$ & Layer $\mathrm{n}^{\mathbf{o}}$ & Material & $\begin{array}{c}\text { Thickness } \\
\text { [mm] }\end{array}$ \\
\hline 1 & HL-P & 50 & 1 & HL-P & 50 & 1 & HL-P & 50 \\
\hline 2 & YNT & 660 & 2 & YNT & 660 & 2 & YNT & 560 \\
\hline 3 & HL-P & 70 & 3 & HL-P & 70 & 3 & HL-P & 70 \\
\hline \multicolumn{2}{|c|}{ Total } & 780 & \multicolumn{2}{|c|}{ Total } & 780 & \multicolumn{2}{|c|}{ Total } & 680 \\
\hline \multicolumn{3}{|c|}{ envelope } & \multicolumn{3}{|c|}{ partition } & \multicolumn{3}{|c|}{ envelope } \\
\hline \multicolumn{3}{|c|}{ LAYOUT B4 } & \multicolumn{3}{|c|}{ LAYOUT B5 } & \multicolumn{3}{|c|}{ LAYOut B6 } \\
\hline 1 & HL-P & 50 & 1 & HL-P & 50 & 1 & HL-P & 50 \\
\hline 2 & YNT & 560 & 2 & YNT & 510 & 2 & YNT & 460 \\
\hline 3 & HL-P & 70 & 3 & HL-P & 70 & 3 & HL-P & 70 \\
\hline \multicolumn{2}{|c|}{ Total } & 680 & \multicolumn{2}{|c|}{ Total } & 630 & \multicolumn{2}{|c|}{ Total } & 580 \\
\hline \multicolumn{3}{|c|}{ partition } & \multicolumn{3}{|c|}{ partition } & \multicolumn{3}{|c|}{ envelope } \\
\hline \multicolumn{3}{|c|}{ Layout B7 } & \multicolumn{3}{|c|}{ Layout B8 } & \multicolumn{3}{|c|}{ LAYOUT B9 } \\
\hline 1 & HL-P & 50 & 1 & HL-P & 50 & 1 & HL-P & 40 \\
\hline 2 & YNT & 460 & 2 & YNT & 360 & 2 & HB & 80 \\
\hline 3 & HL-P & 70 & 3 & HL-P & 70 & 3 & HL-P & 40 \\
\hline \multicolumn{2}{|c|}{ Total } & 580 & \multicolumn{2}{|c|}{ Total } & 480 & \multicolumn{2}{|c|}{ Total } & 160 \\
\hline \multicolumn{3}{|c|}{ partition } & \multicolumn{3}{|c|}{ partition } & \multicolumn{3}{|c|}{ envelope } \\
\hline
\end{tabular}

The software used for the scope was TerMus ${ }^{\circledR}$ by ACCA software, which supports building design with verification of thermal dispersion. This software, working in steady state, is one of the most popular among professionals in South Italy so it was chosen to make the simulation easily referable to the professional sphere. The use of steady state conditions introduces some simplifications in the model, which may lead to different results than using a dynamic simulation. However, the use of this model is in accordance with the law in force (EN ISO 13788/2012) and to recent similar researches [18].

Thermal analysis was conducted setting the coordinates of the settlement area, from which TerMus ${ }^{\circledR}$ retrieved the outdoor air temperatures. The indoor design parameter was fixed at $20{ }^{\circ} \mathrm{C}$ and $26^{\circ} \mathrm{C}$, in winter and summer respectively, with constant $50 \%$ relative humidity.

The walls energy performance, both before and after plaster substitution, was evaluated by means of the parameters and limitations reported in Table 6.

Table 6. Parameters and limitation used for the evaluation of walls energy performance.

\begin{tabular}{ccccc}
\hline \multicolumn{2}{c}{ Parameter } & Legislation & Reference Value \\
\hline $\begin{array}{c}\text { Thermal } \\
\text { admittance }\end{array}$ & $\mathrm{U}$ & {$\left[\mathrm{W} / \mathrm{m}^{2} \mathrm{~K}\right]$} & D.M. 26.06.2015 & $\begin{array}{c}U<0.36 \mathrm{~W} / \mathrm{m}^{2} \mathrm{~K} \text { - climate zone C (a warm } \\
\text { Italian zone) - refurbishment interventions }\end{array}$ \\
\hline $\begin{array}{c}\text { Dynamic thermal } \\
\text { admittance }\end{array}$ & $\mathrm{Y}_{\mathrm{ie}}$ & {$\left[\mathrm{W} / \mathrm{m}^{2} \mathrm{~K}\right]$} & D.M. 26.06.2015 & $\begin{array}{c}Y_{m n}<0.10 \mathrm{~W} / \mathrm{m}^{2} \mathrm{~K} \text { (vertical and inclined walls, } \\
\text { excluding those facing north) }\end{array}$ \\
\hline $\begin{array}{c}\text { Attenuation } \\
\text { coefficient }\end{array}$ & $\mathrm{F}_{\mathrm{a}}$ & $\mid \mathrm{Y}_{\mathrm{ie}} / \mathrm{U}$ & D.M. 26.06.2009 & $\begin{array}{c}F_{a}>0.60 \text { inadequate } \\
F_{a}<0.15 \text { excellent }\end{array}$ \\
\hline
\end{tabular}

The Dynamic thermal admittance $\mathrm{Y}_{\mathrm{ie}}$ estimates the ability of an opaque wall to phase out and attenuate the heat flow passing through it over $24 \mathrm{~h}$. The Attenuation coefficient $\mathrm{F}_{\mathrm{a}}$ expresses the ratio between the amplitudes of the outgoing and incoming heat flows through the wall. Both parameters are a measure of the summer behaviour of the wall, contrary to Thermal admittance, which assesses instead the winter performance.

The overall energy performance of the whole building for both conditions, before and after plaster substitution, was evaluated by using the following performance indexes, according to Italian regulation (D.M. 26.06.2015 [70]): 
- Winter and summer performances are qualitative indexes of the energy requirement needed to meet the indoor comfort, regardless the type and performance of the MEP system. They give an indication of the building (or housing unit) thermal insulation capacity in summer and winter, on a qualitative assessment scale, "high" (-), "medium" $(-)$, "low" (-). In particular, $E P_{H, n d}$ is a general requirement on the building envelope measuring the heating thermal performance and depending on the thermal insulation of the envelope (opaque and transparent), on the performance of a possible ventilation system and on the internal and solar intake. $Y_{I E}$ is the Dynamic thermal admittance averaged on the whole building.

- EPgl,nren is the "non-renewable energy performance index", indicating the amount of energy consumed for the building to reach the comfort conditions. It takes into account the need for non-renewable primary energy for (a) winter and summer air conditioning, (b) production of domestic hot water and (c) ventilation. It is calculated on the basis of the ratio between the energy required to bring an environment to the comfort temperature and its net walkable area. It directly determines the building energy class. The smaller, the better.

- EPgl,ren is the "renewable energy performance index", same as the previous index but applying only to energy produced from renewable sources. The higher, the better.

- $\mathrm{CO}_{2}$ emiss is a measure of the building impact on the environment in terms of estimated carbon dioxide $\left(\mathrm{CO}_{2}\right)$ emissions per year. The lower the value, the less the impact.

- Energy efficiency rating is a score, ranging from G to A4, directly deriving from the "non-renewable energy performance index" (EPgl,nren) by comparing the latter to a predefined scale, in which each step is an energy performance level. The efficiency class scale is based on the value of the "non-renewable energy performance index" of a reference building (EPgl,nren,standard), corresponding to the threshold between classes A1 and B. All other performance levels are obtained by multiplying the asset value (EPgl,nren,standard) by reduction (classes from B to G) or increase (classes from A1 to A4) coefficients.

\section{Results and Discussion}

The design external air temperatures, calculated by the software inputting geographical coordinates of the site, were $1.82{ }^{\circ} \mathrm{C}$ and $32.2^{\circ} \mathrm{C}$, in winter and summer respectively. Figure 3 reports the calculated thermal characteristics of the wall layouts before (A-layouts) and after (B-layouts) the simulated plaster substitution, where " $\mathrm{e}$ " stands for envelope wall and " $\mathrm{p}$ " for partition wall.

\begin{tabular}{|c|c|c|c|c|c|c|c|}
\hline & \multirow[t]{2}{*}{ LAYOUT } & \multicolumn{2}{|c|}{$\begin{array}{c}U \\
{\left[\mathrm{~W} / \mathrm{m}^{2} \mathrm{~K}\right]}\end{array}$} & \multicolumn{2}{|c|}{$\begin{array}{c}\mathrm{Y}_{\mathrm{ie}} \\
{\left[\mathrm{W} / \mathrm{m}^{2} \mathrm{~K}\right]}\end{array}$} & \multicolumn{2}{|c|}{$\begin{array}{l}\mathrm{F}_{\mathrm{a}} \\
{[-]}\end{array}$} \\
\hline & & A-layout & B-layout & A-layout & B-layout & A-layout & B-layout \\
\hline 1 & YNT $660 \mathrm{~mm} \mathrm{e}$ & 1.52 & 0.64 & 0.02 & 0.00 & 0.01 & 0.00 \\
\hline 2 & YNT $660 \mathrm{~mm} \mathrm{p}$ & 1.42 & 0.61 & 0.01 & 0.00 & 0.01 & 0.00 \\
\hline 3 & YNT $560 \mathrm{~mm} \mathrm{e}$ & 1.80 & 0.67 & 0.04 & 0.00 & 0.02 & 0.00 \\
\hline 4 & YNT $560 \mathrm{~mm} p$ & 1.55 & 0.63 & 0.02 & 0.00 & 0.02 & 0.00 \\
\hline 5 & YNT $510 \mathrm{~mm} \mathrm{p}$ & 1.62 & 0.64 & 0.04 & 0.00 & 0.02 & 0.00 \\
\hline 6 & YNT $460 \mathrm{~mm}$ e & 2.01 & 0.69 & 0.10 & 0.01 & 0.05 & 0.01 \\
\hline 7 & YNT 460mm p & 1.70 & 0.65 & 0.05 & 0.00 & 0.03 & 0.01 \\
\hline 8 & YNT $360 \mathrm{~mm} p$ & 1.89 & 0.68 & 0.12 & 0.01 & 0.07 & 0.02 \\
\hline 9 & $\mathrm{HBe}$ & 1.92 & 0.86 & 1.83 & 0.60 & 0.96 & 0.70 \\
\hline
\end{tabular}

Figure 3. Thermal characteristics before (A-layouts) and after (B-layouts) hemp-lime substitution simulation. Red colour means that the property does not meet the regulation limitations; green colour stands for the fulfilment of the requirement. 
Results show that layout thermal properties change according to whether or not the wall outlines the outside. Thermal admittance is always more than halved going from A-layouts to B-layouts, denoting an improved thermal inertia of the walls, in turn indicating fewer thermal dispersions. However, the decrease in thermal admittance is not sufficient, in any case, to meet the regulation requirements, meaning a poor winter performance of the walls.

The dynamic thermal admittance and attenuation coefficient went to zero in most of the B-configurations (100\% reduction). In particular the attained value of the dynamic thermal admittance allowed the results to go from "unacceptable" to "satisfactory" status in two cases, layouts 6 (90\% reduction) and 8 (92\% reduction); conversely for layout 9 (hollow bricks) the value remained above the regulation threshold (67\% reduction). The same happened for the attenuation coefficient, which was fine in all A-layouts $(80 \%, 67 \%$ and $71 \%$ reduction for layouts 6,7 and 8 , respectively) but not 9; although this value decreased $27 \%$ in B-configuration, it was not sufficient to fulfil the standard. Overall, the summer performance of the walls turned out to be improved.

Figure 4 reports the results of the hygrometric test, conducted in steady state, according to EN ISO 13788/2012 [71], where the "yes symbol" ( $\bullet$ indicates that the test gave positive results and the wall was verified against the applied condition. In particular, for the interstitial test, it means that the structure was not subject to interstitial condensation phenomena; for the mould test, it means that the structure was not subject to mould formation. However, in this second test, for both YES and NO outcomes, the software indicated the most critical month, which is also reported in Figure 4.

\begin{tabular}{|c|c|c|c|c|c|c|}
\hline \multirow{2}{*}{\multicolumn{2}{|c|}{ LAYOUT }} & \multicolumn{2}{|c|}{ INTERSTITIAL TEST } & \multicolumn{3}{|c|}{ MOULD TEST } \\
\hline & & A-layout & B-layout & A-layout & B-layout & Most critical month \\
\hline 1 & YNT $660 \mathrm{~mm} \mathrm{e}$ & 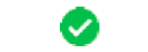 & $\checkmark$ & $\boldsymbol{x}$ & 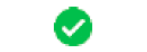 & February \\
\hline 2 & YNT 660mm p & $\checkmark$ & $\checkmark$ & 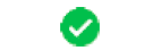 & $\varnothing$ & October \\
\hline 3 & YNT $560 \mathrm{~mm} \mathrm{e}$ & 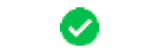 & 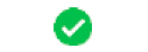 & $\boldsymbol{x}$ & 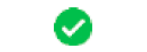 & February \\
\hline 4 & YNT 560mm p & 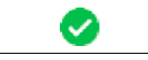 & $\vartheta$ & 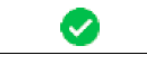 & 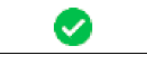 & October \\
\hline 5 & YNT 510mm p & $\checkmark$ & 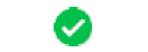 & $\checkmark$ & 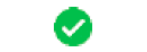 & October \\
\hline 6 & YNT $460 \mathrm{~mm}$ e & $\checkmark$ & 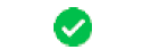 & $x$ & 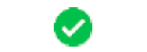 & February \\
\hline 7 & YNT 460mm p & 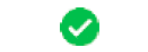 & 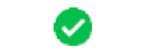 & 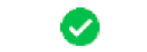 & 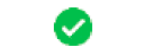 & October \\
\hline 8 & YNT 360mm p & $\checkmark$ & 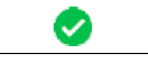 & $\boldsymbol{x}$ & $\vartheta$ & February \\
\hline 9 & $\mathrm{HBe}$ & 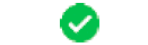 & 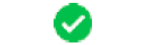 & $\boldsymbol{x}$ & 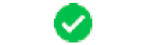 & February \\
\hline
\end{tabular}

Figure 4. Results of the hygrometric tests.

Results show that the interstitial test was always verified, both before and after the simulation. The mould test was not-verified four times out of nine in the "as it is" condition and always verified in the "hemp-lime plaster" condition. This result is consistent with previous studies conducted by other authors [72]. All "not-verified" outcomes corresponded to envelope layouts; conversely, all partitions gave positive results. The mould test critical month was October for partitions and February for envelopes, for both A and B layouts.

\section{Discussion}

The overall energy performance in both conditions, before and after plaster substitution, is summarized in Figure 5. 


\begin{tabular}{|c|c|c|c|c|c|c|}
\hline & $\begin{array}{c}\text { Winter } \\
\text { performance }\end{array}$ & $\begin{array}{c}\text { Summer } \\
\text { performance }\end{array}$ & $\begin{array}{c}\text { EPgl,nren } \\
{\left[\mathrm{kWh} / \mathrm{m}^{2} \mathrm{y}\right]}\end{array}$ & $\begin{array}{c}E P g l, \text { ren } \\
{\left[\mathrm{kWh} / \mathrm{m}^{2} \mathrm{y}\right]}\end{array}$ & $\begin{array}{c}\mathrm{CO}_{2} \\
\text { emiss. } \\
{\left[\mathrm{kg} / \mathrm{m}^{2} \mathrm{y}\right]}\end{array}$ & Energy efficiency rating \\
\hline A & (0) & (0) & \multirow[t]{2}{*}{141.27} & \multirow[t]{2}{*}{0.24} & \multirow[t]{2}{*}{26.53} & \multirow{2}{*}{ 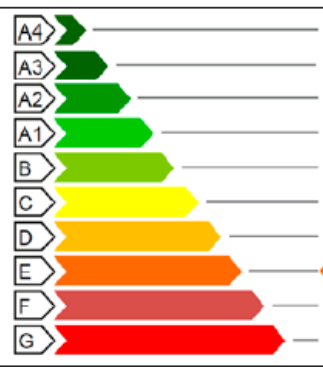 } \\
\hline as it is & $\begin{array}{c}E P_{H, \text { nd }} \\
{\left[\mathrm{kWh} / \mathrm{m}^{2} \mathrm{y}\right]} \\
152.43 \\
\end{array}$ & $\begin{array}{c}Y_{1 E} \\
{\left[W / \mathrm{m}^{2} \mathrm{~K}\right]} \\
0.16 \\
\end{array}$ & & & & \\
\hline $\begin{array}{c}\text { B } \\
\text { with }\end{array}$ & (0) & $\begin{array}{l}(0) \\
0 \\
0\end{array}$ & \multirow[t]{2}{*}{112.63} & \multirow[t]{2}{*}{0.24} & \multirow[t]{2}{*}{21.15} & \multirow{2}{*}{ 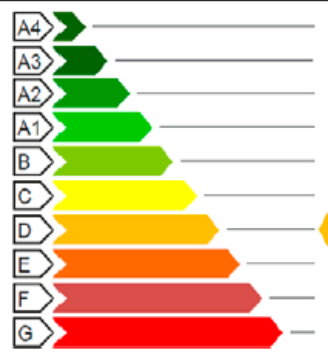 } \\
\hline $\begin{array}{l}\text { hemp- } \\
\text { lime } \\
\text { plaster }\end{array}$ & $\begin{array}{c}\begin{array}{c}E P_{H, n d} \\
{\left[k W h / m^{2} y\right]}\end{array} \\
86.13\end{array}$ & $\begin{array}{c}Y_{\mathbb{E}} \\
{\left[\mathrm{W} / \mathrm{m}^{2} \mathrm{~K}\right]} \\
0.11\end{array}$ & & & & \\
\hline
\end{tabular}

Figure 5. Overall energetic performance.

Although the winter performance index (Figure 5, column 2) after the simulated intervention remained in the "low quality class", the insulation capacity was almost doubled $(-43 \%)$. In fact, the amount of energy required to reach the indoor comfort during winter went from $152.43 \mathrm{kWh} / \mathrm{m}^{2}$ per year to only 86.13. The increase in thermal insulation power was also registered in summer condition (Figure 5, column 3), where the $\mathrm{Y}_{\mathrm{IE}}$ index decreased 30\%, yielding to an improvement of "quality class", from "low" to "medium". This is also reflected by the decreased need for non-renewable primary energy, calculated by means of the global "non-renewable energy performance index" (Figure 5, column 4), which went from $141.27 \mathrm{kWh} / \mathrm{m}^{2}$ per year to 112.63 . The "renewable energy performance index" (Figure 5, column 5) instead was stable, as no changes in the MEP systems were planned and the value of 0.24 was a consequence of the fact that the heating system was natural gas (methane) powered. $\mathrm{CO}_{2}$ emissions (Figure 5, column 6) had a $20 \%$ reduction, going from 26 to $21 \mathrm{~kg} / \mathrm{m}^{2}$ per year. The $20 \%$ decrease in the EPgl,nren index brings the examined building one level up in the EU energy label classifications (Figure 5, column 7), from E class to D class, which can be considered a good result bearing in mind that the simulated intervention affects only the wall plasters not covered by frescoes.

Focusing on the economic aspect, realizing $1 \mathrm{~m}^{2}$ plaster with a thickness, for example, of $15 \mathrm{~mm}$ would cost $5.00 €$ and $15.50 €$ in row materials using a standard gypsum-lime plaster and a hemp-lime one, respectively. To this value, the labour cost should also be added, at different percentages depending on the technique required for the plaster laying: the product cost is around $70 \%$ for gypsum-lime (hand-coating process) and around 30\% for hemp-lime (considering the spraying procedure). The total cost is $16.00 €$ for gypsum-lime and $22.00 €$ for hemp-lime plaster $[65,66]$.

\section{Conclusions}

To increase the use of hemp in the AEC sector, the industrial production of this material needs to be profitable and competitive from an economic standpoint, creating coordinated actions, which affect different aspects of this particular industrial sector. Improving awareness for conscious consumption may contribute to the reduction of barriers hampering the establishment of hemp use.

In order to evaluate the energetic performance of hemp-lime plaster, a refurbishment intervention on a real case study building was simulated, substituting the standard gypsum-lime plaster with 
a hemp-lime one. The energetic performance of the selected building was assessed in the present condition and hypothesized refurbishment scenario.

The results show that hemp-lime based plaster is capable of decreasing thermal dispersions by more than halving the thermal admittance and reducing to at least one third (but in other cases to one tenth or to zero) the dynamic thermal admittance and attenuation coefficient of the walls. However, the decrease in thermal admittance for all layouts was not sufficient to fulfil the regulatory requirements, which is why the winter performance of the entire building remains in the lowest qualitative class. Conversely, the application of hemp-lime plaster enabled meeting the limits established for dynamic thermal admittance and attenuation coefficient in all layouts but the hollow bricks one, resulting in an improvement to the summer performance class, from low to medium. With reference to steady state conditions, hemp-lime also eliminates the risk of moulds formation.

The overall energy performance of the building registers an improvement of approximately $20 \%$ compared to the condition with traditional gypsum-lime plaster, with a subsequent $20 \%$ decrease also in $\mathrm{CO}_{2}$ emissions. This corresponds to a one-level improvement of the building energy class, from $\mathrm{E}$ to D. Although the building is still very far from A1 class, the obtained result can be considered satisfying, as the modelled improvement intervention concerns only substitution of most of the wall plasters.

Author Contributions: Conceptualization, all authors; methodology, R.A. and L.M.; validation, R.A.; data curation, R.A.; writing-original draft preparation, all authors; writing-review and editing, all authors; visualization, R.A. and P.P.; supervision, A.M. and L.M.. All authors have read and agreed to the published version of the manuscript.

Funding: This research received no external funding.

Conflicts of Interest: The authors declare no conflict of interest.

\section{References}

1. Marino, A.; Pariso, P. Comparing European countries' performances in the transition towards the Circular Economy. Sci. Total Environ. 2020. [CrossRef] [PubMed]

2. Marino, A.; Pariso, P. E-Government and its Impact on National Economic Development: A Case Study Concerning Southern Italy International. In Proceedings of the 3rd International Conference on E-Commerce, E-Business and E-Government, ICEEG, Lyon, France, 18-21 June 2019.

3. Chang, R.D.; Zuo, J.; Soebarto, V.; Zhao, Z.Y.; Zillante, G.; Gan, X.L. Discovering the transition pathways toward sustainability for construction enterprises: Importance-performance analysis. J. Constr. Eng. Manag. 2017, 143, 04017013. [CrossRef]

4. Hsiao, T.Y.; Huang, Y.T.; Yu, Y.H.; Wernick, I.K. Modeling materials flow of waste concrete from construction and demolition wastes in Taiwan. Resour. Policy 2002, 28, 39-47. [CrossRef]

5. Kim, S.; Vyas, R.; Bito, J.; Niotaki, K.; Collado, A.; Georgiadis, A.; Tentzeris, M.M. Ambient RF Energy-Harvesting Technologies for Self-Sustainable Standalone Wireless Sensor Platforms. Proc. IEEE 2014, 102, 1649-1666. [CrossRef]

6. Tatari, O.; Kucukvar, M. Eco-efficiency of construction materials: Data envelopment analysis. J. Constr. Eng. Manag. 2011, 138, 733-741. [CrossRef]

7. Muller, M.F.; Esmanioto, F.; Huber, N.; Loures, E.R.; Junior, O.C. A systematic literature review of interoperability in the green Building Information Modeling lifecycle. J. Clean. Prod. 2019, 223, 397-412. [CrossRef]

8. Sinka, M.; Radina, L.; Sahmenko, G.; Korjakins, A.; Bajare, D. Enhancement of Lime-Hemp Concrete Properties Using Different Manufacturing Technologies. In Proceedings of the First International Conference on Bio-Based Building Materials, Clermont-Ferrand, France, 22-24 June 2015; pp. 1-8.

9. Liobikienè, G.; Butkus, M. The European Union possibilities to achieve targets of Europe 2020 and Paris agreement climate policy. Renew. Energy 2017, 106, 298-309. [CrossRef]

10. 10. European Parliament, Council of the European Union. Directive 2010/31/EU of the European Parliament and of the Council of 19 May 2010 on the energy performance of buildings and Subsequent Amendments and Additions. Off. J. Eur. 2010, 3, 124-146.

11. European Council (23 and 24 October 2014)—Conclusions, Energy and Climate Framework 2030. Available online: https://ec.europa.eu/clima/policies/strategies/2030_en\#tab-00-- (accessed on 10 February 2020). 
12. Adamczyk, J.; Dylewski, R. The impact of thermal insulation investments on sustainability in the construction sector. Renew. Sustain. Energy Rev. 2017, 80, 421-429. [CrossRef]

13. Bevan, R.; Woolley, T. Hemp Lime Construction. A Guide to Building with Hemp Lime Composites; BRE Electronic Publications: Bracknell, UK, 2008.

14. Martabid, J.E.; Mourgues, C. Criteria used for selecting envelope wall systems in Chilean residential projects. J. Constr. Eng. Manag. 2015, 141, 05015011. [CrossRef]

15. Arroyo, P.; Tommelein, I.D.; Ballard, G. Selecting globally sustainable materials: A case study using choosing by advantages. J. Constr. Eng. Manag. 2015, 142, 05015015. [CrossRef]

16. Energy Efficiency for EU Historic Districts Sustainability (EFFESUS). Available online: https://www.effesus.eu (accessed on 21 May 2020).

17. Robust Internal Thermal Insulation of Historic Buildings (RiBuild). Available online: https://www.ribuild.eu (accessed on 21 May 2020).

18. Lucchi, E.; Roberti, F.; Alexandra, T. Definition of an experimental procedure with the hot box method for the thermal performance evaluation of inhomogeneous walls. Energy Build. 2018, 179, 99-111. [CrossRef]

19. Lucchi, E.; Becherini, F.; Di Tuccio, M.C.; Troi, A.; Frick, J.; Roberti, F.; Bernardi, A. Thermal performance evaluation and comfort assessment of advanced aerogel as blown-in insulation for historic buildings. Energy Build. 2017, 122, 258-268. [CrossRef]

20. Lucchi, E.; Tabak, M.; Troi, A. The "cost optimality" approach for the internal insulation of historic buildings. Energy Procedia 2017, 133, 412-423. [CrossRef]

21. Di Giuseppe, E.; D’Orazio, M.; Du, G.; Favi, C.; Lasvaux, S.; Maracchini, G.; Padey, P. A stochastic approach to LCA of internal insulation solutions for historic buildings. Sustainability 2020, 12, 1535. [CrossRef]

22. Brostrom, T.; Bernardi, A.; Egusquiza, A.; Frick, J.; Kahn, M. A Method for Categorization of European Historic Districts and a Multiscale Data Model for the Assessment of Energy Interventions. 2013. Available online: https://www.effesus.eu/wp-content/uploads/2016/02/EWCHP-2013-Effesus-final.pdf (accessed on 18 May 2020).

23. Bianco, L.; Serra, V.; Fantucci, S.; Dutto, M.; Massolino, M. Thermal insulating plaster as a solution for refurbishing historic building envelopes: First experimental results. Energy Build. 2015, 95, 86-91. [CrossRef]

24. Walker, R.; Pavía, S. Thermal performance of a selection of insulation materials suitable for historic buildings. Build. Environ. 2015, 94, 155-165. [CrossRef]

25. Moretti, E.; Belloni, E.; Agosti, F. Innovative mineral fiber insulation panels for buildings: Thermal and acoustic characterization. Appl. Energy 2016, 169, 421-432. [CrossRef]

26. Pineda, P.; García-Martínez, A.; Castizo-Morales, D. Environmental and structural analysis of cement-based vs. natural material-based grouting mortars. Results from the assessment of strengthening works. Constr. Build. Mater. 2017, 138, 528-547. [CrossRef]

27. Blumberga, A.; Kass, K.; Kamendere, E.; Žogla, G.; Kamenders, A.; Blumberga, D.; Grāvelsinšs, A.; Purviňš, R.; Rošā, M.; Timma, L.; et al. Robust Internal Thermal Insulation of Historic Buildings-State of the Art on Historic Building Insulation Materials and Retrofit Strategies; RiBuild Project; pp. 1-87. Available online: https://irias.kuleuven.be/retrieve/550350 (accessed on 18 May 2020).

28. Dario, B.-L.; Marco, L.; Daniel, H.-A.; Franziska, H.; Alexandra, T. Evaluation of natural-based internal insulation systems in historic buildings through a holistic approach. Energy 2019, 181, 521-531.

29. Eriksson, P.; Hermann, C.; Hrabovszky-Horvath, S.; Rodwell, D. EFFESUS Methodology for Assessing the Impacts of Energy-Related Retrofit Measures on Heritage Significance. 2014. Available online: https: //www.effesus.eu/dissemination/publications (accessed on 19 May 2020).

30. Nowotna, A.; Pietruszka, B.; Lisowski, P. Eco-Friendly Building Materials. In IOP Conference Series: Earth and Environmental Science; IOP Publishing: Bristol, UK, 2019; Volume 290, p. 012024.

31. Stapulionienè, R.; Vaitkus, S.; Vejjelis, S.; Sankauskaite, A. Investigation of thermal conductivity of natural fibres processed by different mechanical methods. Int. J. Precis. Eng. Manuf. 2016, 17, 1371-1381. [CrossRef]

32. Yılmaz, M.; Bakış, A. Sustainability in construction sector. Procedia Soc. Behav. Sci. 2015, 195, $2253-2262$. [CrossRef]

33. Khodeir, L.M.; Othman, R. Examining the interaction between lean and sustainability principles in the management process of AEC industry. Ain Shams Eng. J. 2018, 9, 1627-1634. [CrossRef]

34. Kidalova, L.; Stevulova, N.; Terpakova, E.; Helcman, M. Effective utilization of alternative materials in lightweight composites. Chem. Eng. Trans. 2011, 25, 1079-1084. 
35. Kidalova, L.; Stevulova, N.; Terpakova, E.; Sicakova, A. Utilization of alternative materials in lightweight composites. J. Clean. Prod. 2012, 34, 116-119. [CrossRef]

36. Pergamo, R.; Briamonte, L.; Cerrato, D. The textile hemp chain: Value analysis, economic and environmental benefits. Calitatea 2018, 19, 375-378.

37. European Commission. 2019. Available online: https://ec.europa.eu/info/news/new-rules-greener-andsmarter-buildings-will-increase-quality-life-all-europeans-2019-apr-15_en] (accessed on 18 May 2020).

38. Amann, M.; Holland, M.; Maas, R.; Vandyck, T.; Saveyn, B. Costs, Benefits and Economic Impacts of the EU Clean Air Strategy and their Implications on Innovation and Competitiveness; IIASA Report; International Institute for Applied Systems Analysis (IIASA): Laxenburg, Austria, 2017.

39. European Commission. 2017. Available online: https://ec.europa.eu/eurostat/news/themes-in-the-spotlight/ household-expenditure-2017 (accessed on 18 May 2020).

40. European Commission. 2016. Available online: https:/ec.europa.eu/commission/presscorner/detail/en/ MEMO_16_3986 (accessed on 18 May 2020).

41. European Commission. 2016. Available online: https://eur-lex.europa.eu/legal-content/EN/TXT/HTML/ ?uri=CELEX:52016DC0860from=EN (accessed on 18 May 2020).

42. Sassoni, E.; Manzi, S.; Motori, A.; Montecchi, M.; Canti, M. Novel sustainable hemp-based composites for application in the building industry: Physical, thermal and mechanical characterization. Energy Build. 2014, 77, 219-226. [CrossRef]

43. Hussain, A.; Calabria-Holley, J.; Lawrence, M.; Ansell, M.P.; Jiang, Y.; Schorr, D.; Blanchet, P. Development of novel building composites based on hemp and multi-functional silica matrix. Compos. Part B Eng. 2019, 156, 266-273. [CrossRef]

44. Costantine, G.; Maalouf, C.; Moussa, T.; Polidori, G. Experimental and numerical investigations of thermal performance of a Hemp Lime external building insulation. Build. Environ. 2018, 2018 131, 140-153. [CrossRef]

45. Awwad, E.; Mabsout, M.; Hamad, B.; Farran, M.T.; Khatib, H. Studies on fiber-reinforced concrete using industrial hemp fibers. Constr. Build. Mater. 2012, 35, 710-717. [CrossRef]

46. Jami, T.; Karade, S.; Singh, L.P. Hemp Concrete-A traditional and novel green building material. In Proceedings of the International Conference on Advances in Construction Materials and Structures, IIT Roorkee, Roorkee, Uttarakhand, India, 7-8 March 2018; p. 8.

47. Walker, R.; Pavía, S. Thermal and moisture monitoring of an internally insulated historic brick wall. Build. Environ. 2018, 133, 178-186. [CrossRef]

48. Maalouf, C.; Ingrao, C.; Scrucca, F.; Moussa, T.; Bourdot, A.; Tricase, C.; Asdrubali, F. An energy and carbon footprint assessment upon the usage of hemp-lime concrete and recycled-PET façades for office facilities in France and Italy. J. Clean. Prod. 2018, 170, 1640-1653. [CrossRef]

49. Agliata, R.; Gianoglio, S.; Mollo, L. Hemp-lime composite for buildings insulation: Material properties and regulatory framework. Vitr. Int. J. Archit. Technol. Sustain. 2018, 4, 48-57. [CrossRef]

50. Arrigoni, A.; Pelosato, R.; Melia, P.; Ruggieri, G.; Sabbadini, S.; Dotelli, G. Life cycle assessment of natural building materials: The role of carbonation, mixture components and transport in the environmental impacts of hempcrete blocks. J. Clean. Prod. 2017, 149, 1051-1061. [CrossRef]

51. Busbridge, R.; Rhydwen, R. An investigation of the thermal properties of hemp and clay monolithic walls. In Proceedings of the Advances in Computing and Technology, (AC\&T) The School of Computing and Technology 5th Annual Conference, London, UK, 14 September 2010.

52. Cerezo, V. Propriétés mécaniques, thermiques et acoustiques d'un matériau à base de particules végétales: Approche éxpérimentale et modélisation théorique. Inst. Natl. Des Sci. Appliquées De Lyon 2005, 1, 229-234.

53. Ronchetti, P. Il Cemento di Canapa e Calce: Un Promettente Materiale e Metodo di Costruzione per L'edilizia Sostenibile. 2007. Available online: http://www.canapa-info.ch/info/pt/IMG/pdf/Cemento_di_canapa_ e_calce_-_promettente_materiale_e_metodo_di_costruzione_per_l_edilizia_sostenibile.pdf (accessed on 15 May 2020).

54. Walker, R.; Pavía, S. Moisture transfer and thermal properties of hemp-lime concretes. Constr. Build. Mater. 2014, 64, 270-276. [CrossRef]

55. Campolongo, G.; Chiaravallotti, R.; Pinoni, M. La Svalutazione Dell'immobile per Difetto dei Requisiti Acustici; Maggioli Ed.: Rimini, Italy, 2011. 
56. Building Research Establishment. Fire Resistance Test in accordance with BS EN 1365-1:1999 on a Lime Technology $3 \times 3$ m Tradical-Hemcrete Loaded Wall; Test Report 250990; Environmental Protection Agency: Wexford, Ireland, 2009.

57. Murphy, F.; Pavia, S. and Walker, R. An Assessment of the Physical Properties of Lime-Hemp Concrete. In Proceeding of the Bridge and Concrete Research in Ireland, Dublin, Ireland, 6-7 September 2012.

58. Benfratello, S.; Capitano, C.; Peri, G.; Rizzo, G.; Scaccianoce, G.; Sorrentino, G. Thermal and structural properties of a hemp-lime biocomposite. Constr. Build. Mater. 2013, 48, 745-754. [CrossRef]

59. Daly, P.; Ronchetti, P.; Woolley, T. Hemp Lime Bio-Composite as a Building Material Irish Construction; Environmental Protection Agency: Wexford, Ireland, 2012.

60. Bouloc, P.; Allegret, S.; Arnaud, L. Hemp: Industrial Production and Uses; CABI: Wallingford, UK, 2013.

61. Carus, M.; Sarmento, L. The European Hemp Industry: Cultivation, Processing and Applications for Fibres, Shivs, Seeds and Flowers; European Industrial Hemp Association (EIHA): Huerth, Germany, 2017; pp. 1-9.

62. Sacilik, K.; Öztürk, R.; Keskin, R. Some physical properties of hemp seed. Biosyst. Eng. 2003, 86, $191-198$. [CrossRef]

63. Fortenbery, T.R.; Bennett, M. Opportunities for commercial hemp production. Rev. Agric. Econ. 2004, 26, 97-117. [CrossRef]

64. Forlani, M.C.; Radogna, D.; Mastrolonardo, L. Hemp for a healthy and sustainable building in Abruzzo. In Intelligent Human System Integration, Proceedings of the 1st international Conference IHSINT, Dubai, UAE, 7-9 January 2018; Springer: Dubai, UAE, 2018.

65. Smith, B.C. Hemp Testing Insanity. Cannabis Sci. Technol. 2019, 2, 10-13.

66. Posani, M.; Veiga, M.D.R.; de Freitas, V.P. Towards Resilience and Sustainability for Historic Buildings: A Review of Envelope Retrofit Possibilities and a Discussion on Hygric Compatibility of Thermal Insulations. Int. J. Archit. Herit. 2019, 1-17. [CrossRef]

67. Strandberg-de Bruijn, P.; Donarelli, A.; Balksten, K. Full-scale Studies of Improving Energy Performance by Renovating Historic Swedish Timber Buildings with Hemp-lime. Appl. Sci. 2019, 9, 2484. [CrossRef]

68. Available online: http://agricoltura.regione.campania.it/canapa/canapa.html (accessed on 18 May 2020).

69. Mazhoud, B.; Collet, F.; Pretot, S.; Chamoin, J. Hygric and thermal properties of hemp-lime plasters. Build. Environ. 2016, 96, 206-216. [CrossRef]

70. Italian Ministry of Economic Development. Decreto interministeriale 26 giugno 2015 "Applicazione delle metodologie di calcolo delle prestazioni energetiche e definizione delle prescrizioni e dei requisiti minimi degli edifici", ai sensi dell'articolo articolo 4, comma 1, del decreto legislativo 19 agosto 2005, $n$. 192, con relativi allegati 1 (e rispettive appendici $A$ e B) e 2; Italian Ministry of Economic Development: Rome, Italy, 2005.

71. European Committee for Standardization. Hygrothermal Performance of Building Components and Building Elements-Internal Surface Temperature to Avoid Critical Surface Humidity and Interstitial Condensation-Calculation Methods; EN ISO 13788: 2012; European Committee for Standardization: Bruxelles, Belgium, 2012.

72. Claude, S.; Ginestet, S.; Bonhomme, M.; Escadeillas, G.; Taylor, J.; Marincioni, V.; Altamirano, H. Evaluating retrofit options in a historical city center: Relevance of bio-based insulation and the need to consider complex urban form in decision-making. Energy Build. 2019, 182, 196-204. [CrossRef]

(C) 2020 by the authors. Licensee MDPI, Basel, Switzerland. This article is an open access article distributed under the terms and conditions of the Creative Commons Attribution (CC BY) license (http://creativecommons.org/licenses/by/4.0/). 